\title{
GROWTH RESPONSES OF FIVE NON TOXIC ALEXANDRIUM SPECIES (DINOPHYCEAE) TO TEMPERATURE AND SALINITY
}

\author{
Po-Teen Lim ${ }^{1 *}$, Chui-Pin Leaw, Shinnosuke Kaga ${ }^{2,3}$, Katsushi Sekiguchi $^{3}$, Takehiko Ogata ${ }^{2}$ \\ ${ }^{1}$ Aquatic Program, Faculty of Resource Science and Technology \\ Universiti Malaysia Sarawak, 94300 Kuching, Sarawak, Malaysia. \\ ${ }^{2}$ School of Fisheries Sciences, Kitasato University, Ofunato City, Iwate, 022-0101 Japan. \\ ${ }^{3}$ Iwate Fisheries Technology Center, Kamaishi, Iwate 026-001, Japan \\ "e-mail:ptlim@frst.unimas.my; poteen_lim@yahoo.com
}

\begin{abstract}
Growth response of five clonal cultures of Alexandrium obtained from tropical and temperate waters were examined. Experiments were carried out in eighteen variable temperature-salinity conditions (temperatures of $15^{\circ} \mathrm{C}$, $20^{\circ} \mathrm{C}$, and $25^{\circ} \mathrm{C}$; salinities between 5 to $30 \mathrm{psu}$ ) under constant illumination of $150 \pm 10.0 \mu \mathrm{mol} \mathrm{m}^{-2} \mathrm{~s}^{-1}$ at $15: 9$ light:dark photo-cycle. Our results showed optimum growth of all Alexandrium species at $20-25^{\circ} \mathrm{C}$. The salinity range for optimum growth however varied among the species. Growth rates of $A$. affine, $A$. insuetum, and $A$. fraterculus $(0.28$ -0.37 day $\left.^{-1}\right)$ were higher than those of $A$. leei and $A$. pseudogoniaulax under the same culture conditions $(0.14-$ 0.22 day $\left.^{-1}\right)$. The three temperate species showed positive growth at suboptimum temperature, $15^{\circ} \mathrm{C}$, but the tropical species did not grow and died off. Salinity tolerance of the five species in decreasing order was $A$. pseudogoniaulax $>$ A. leei $>$ A. insuetum $>$ A. affine $>$ A. fraterculus. Results of the present study showed vast variations in salinity tolerance among the Alexandrium species regardless the geographical origins. Adaptation of the temperate species at higher temperature indicated that the species might proliferate in warm tropical waters.
\end{abstract}

Keywords: Alexandrium, Growth, Salinity, Temperature

\section{INTRODUCTION}

The genus Alexandrium Halim comprised of more than 30 species. Approximately one-third of these species capable of producing a suit of sodium channel blocking toxins or commonly known as paralytic shellfish toxins (PSTs). Various researches have been carried out to gain better understanding of the eco-physiology of Alexandrium species, however these studies were mainly carried out on $A$. tamarense (Lebour) Balech (Ogata et al., 1987), A. fundyense Balech (Anderson et al., 1990), A. minutum Halim (Flynn et al., 1994; Chang and McClean, 1997), and $A$. tamiyavanichii Balech (Previously as Protogonyaulax cohorticula) (Ogata et al., 1989; Lim and Ogata, 2005).

Little is known about the ecology and physiology of non toxic Alexandrium species. Some of these non PSTs producing species have been shown to be distributed worldwide and cooccurrence with the toxic counterpact, while some caused negative impact on marine environment or its flora and fauna (Delgado et al., 1997)). In tropical waters, high precipitation coupled with strong freshwater output has been resulted in salinity fluctuation in the estuarine waters. On the other hand, temperature showed significant seasonal variation in higher latitude. It is generally presumed that the species from different geographical regions possess specific ecological adaptation to the natural environments where they are originated. To test the hypothesis that tropical Alexandrium species is more euryhaline while the temperate species is more eurythermal, growths of five Alexandrium species originated from both tropical and temperate waters were examined in eighteen variable temperature-salinity conditions.

\section{MATERIALS AND METHODS}

\section{Cultures}

Clonal cultures of tropical $A$. affine and $A$. leei were established from live plankton 
specimens collected from Malaysian waters as described earlier (Usup et al., 2002), while the temperate isolates of $A$. insuetum, $A$. pseudogoniaulax and $A$. fraterculus were obtained from Sanriku coast, northeastern of Japan (Kaga et al., in press). Cultures were maintained in ES-DK medium (Kokinos and Anderson, 1995) under a light intensity of $150 \pm 10.0 \mu \mathrm{mol} \mathrm{m}^{-2} \mathrm{~s}^{-1}$ and 15:9 hour light:dark photoperiod. Natural seawater (35 psu) from Okkirai Bay, Japan was used as the medium base. Stock cultures of tropical and temperate strains were maintained at $25^{\circ} \mathrm{C}$ and $20^{\circ} \mathrm{C}$ respectively.

\section{Salinity and Temperature Experimental Design and Setup}

Salinity and temperature experiment was carried out in eighteen variable temperature-salinity treatments, with salinities $5,10,15,20,25$, and 30 psu and temperatures 15,20 and $25^{\circ} \mathrm{C}$. All treatments were in duplicate. Salinity was adjusted by diluting with deionized distilled water to desired salinity. Exponential-phase cells were then used as inoculates to prepare $25 \mathrm{~mL}$ batch cultures. Growth was determined daily or alternate day by in vivo fluorescence and cell counts using light microscope. Relationship between in vivo fluorescence and cell density for each species was established by obtaining cell density at respective in vivo fluorescence reading. Specific growth rate $\left(1 / 4\right.$, day $\left.^{-1}\right)$ was then calculated from in vivo fluorescence-estimated cell density during the exponential growth phase using the following equation:

$$
\mu=\frac{\ln N_{1}-\ln N_{0}}{t_{1}-t_{0}}
$$

where $\mathrm{N}$ is the estimated cell density at time $t$.

\section{RESULTS}

\section{In Vivo Fluorescence Measurement of Cell Growth}

Growth of five species was monitored using in vivo fluorescence and microscopic cell count. There were strong correlations between in vivo fluorescence and microscopy cell counts in all the species examined ( $A$. affine, $\mathrm{r}^{2}=0.96, \mathrm{P}<0.0001$; A. leei, $\mathrm{r}^{2}=0.95, \mathrm{P}<0.0001 ; A$. insuetum, $\mathrm{r}^{2}=$ $0.99, \mathrm{P}<0.0001 ;$ A. fraterculus, $\mathrm{r}^{2}=0.94$, $\mathrm{P}<0.0001 ; A$. pseudogoniaulax, $\mathrm{r}^{2}=0.98$, $\mathrm{P}<0.0001)$ during the exponential growth phase (Fig. 1). This allowed the estimation of cell density from the in vivo fluorescent measurements (Fig. 1).

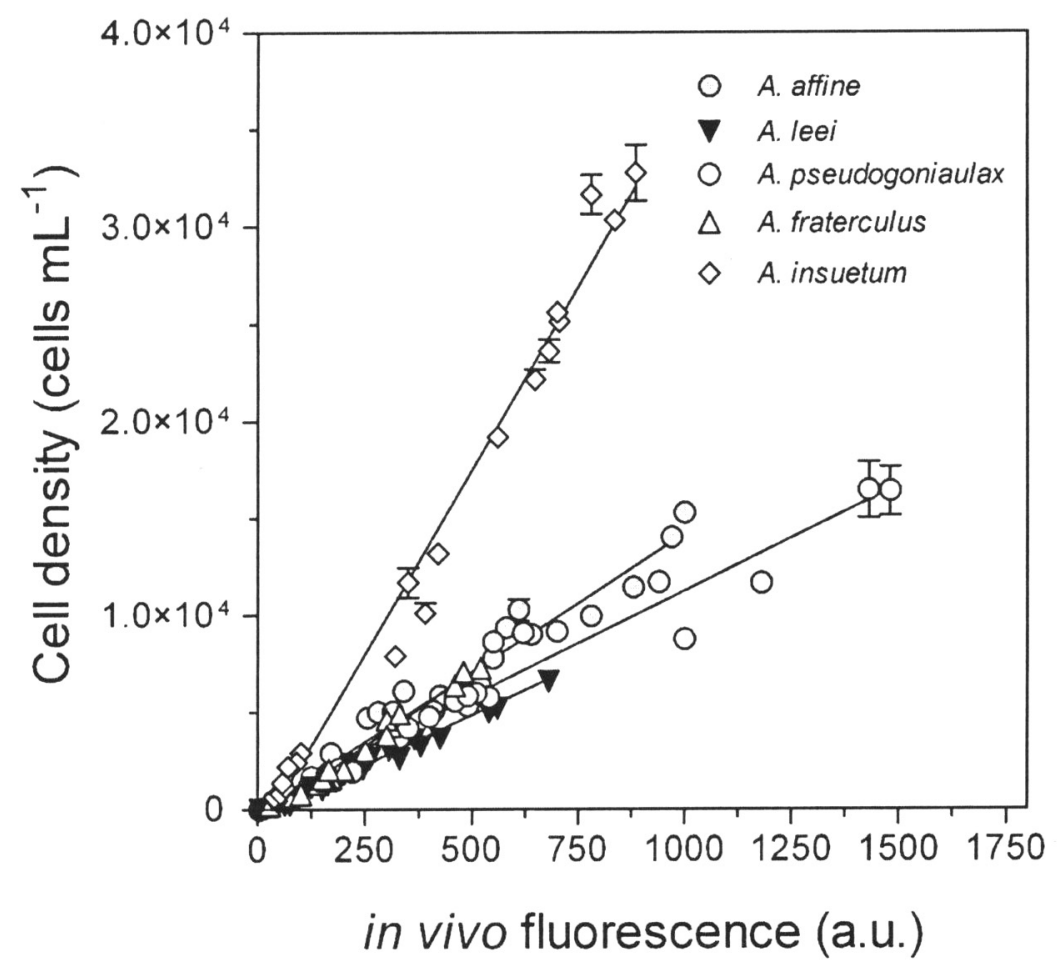

Figure 1. Relationship of cell density and in vivo fluorescence of the five Alexandrium species. 


\section{Effects of Temperature and Salinity on Cell Growth}

All Alexandrium species in the present study showed optimum growth at $20-25^{\circ} \mathrm{C}$ (Fig. 2). At $15^{\circ} \mathrm{C}$, only temperate strains of $A$. insuetum, $A$. pseudogoniaulax, and $A$. fraterculus grew suboptimally with low positive growth rates $(>0.02$ day $\left.^{-1}\right)$. The two tropical species of $A$. affine and A. leei however did not grow and died off after

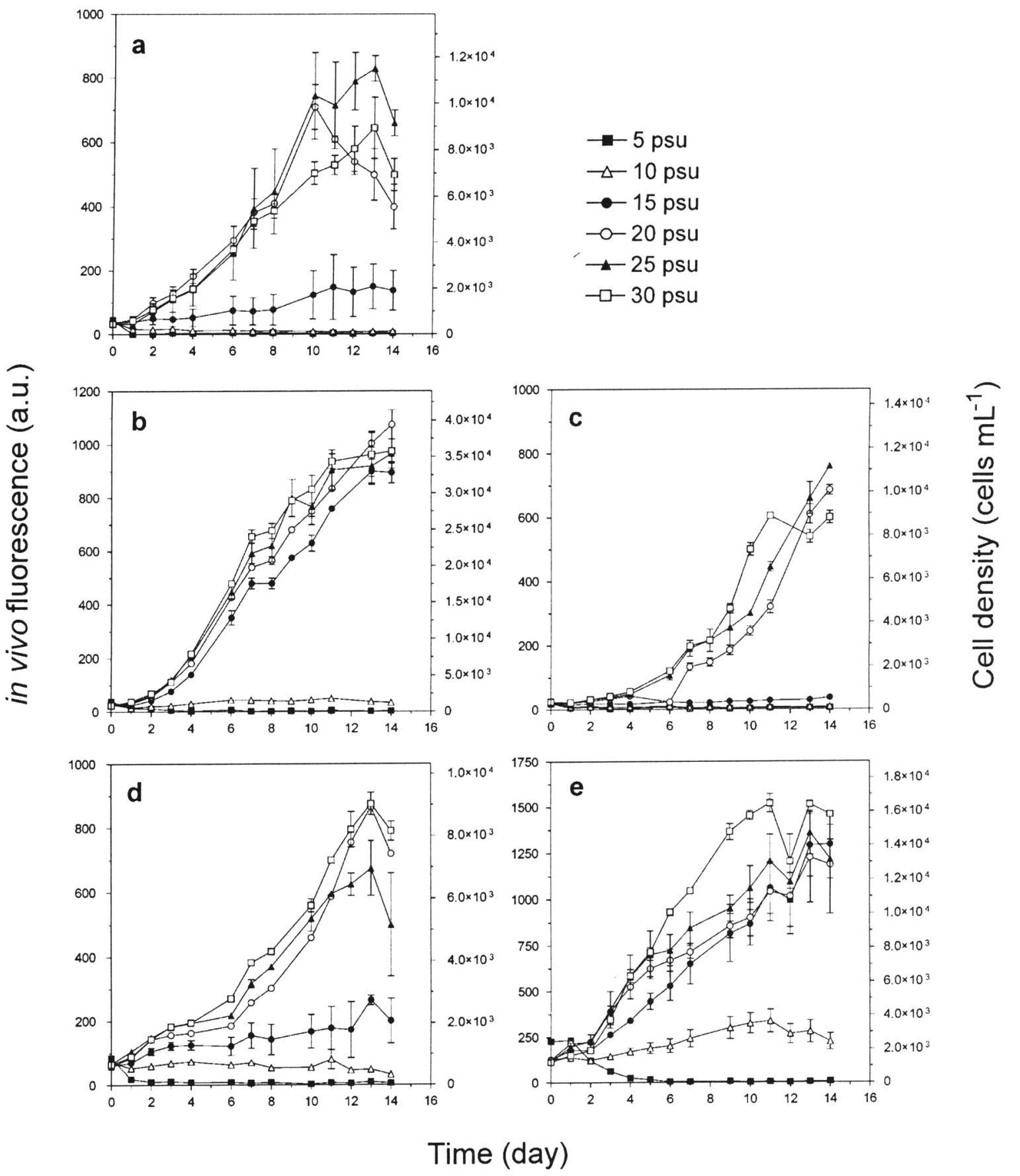

Figure 2. Growths of Alexandrium species under various salinities at $25^{\circ} \mathrm{C}$ by in vivo fluorescent measurement. (a)

A. affine, (b) A. insuetum, (c) A. fraterculus, (d) A. leei, (e) A. pseudogoniaulax.
The optimum salinity of tropical $A$. affine was observed within the range of 20 to 30 psu $(0.19$ 0.37 day $^{-1}$ ) with the highest growth rate at $25 \mathrm{psu}$ (Fig. 3). The species did not grow at 10 psu or lower. At low temperature $\left(15^{\circ} \mathrm{C}\right)$, no growth was observed in $A$. affine. The optimum salinity regime for $A$. insuetum was observed within 15 to $30 \mathrm{psu}$ $\left(0.29-0.34\right.$ day $\left.^{-1}\right)$ with the highest growth rate at $20^{\circ} \mathrm{C}$ and a salinity of $30 \mathrm{psu}$. Growth rates did not 


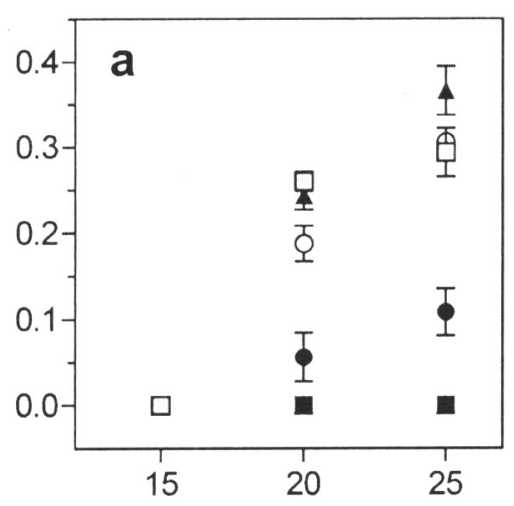

- 5 psu

$\triangle 10$ psu

- 15 psu

- 20 psu

- 25 psu

$30 \mathrm{psu}$
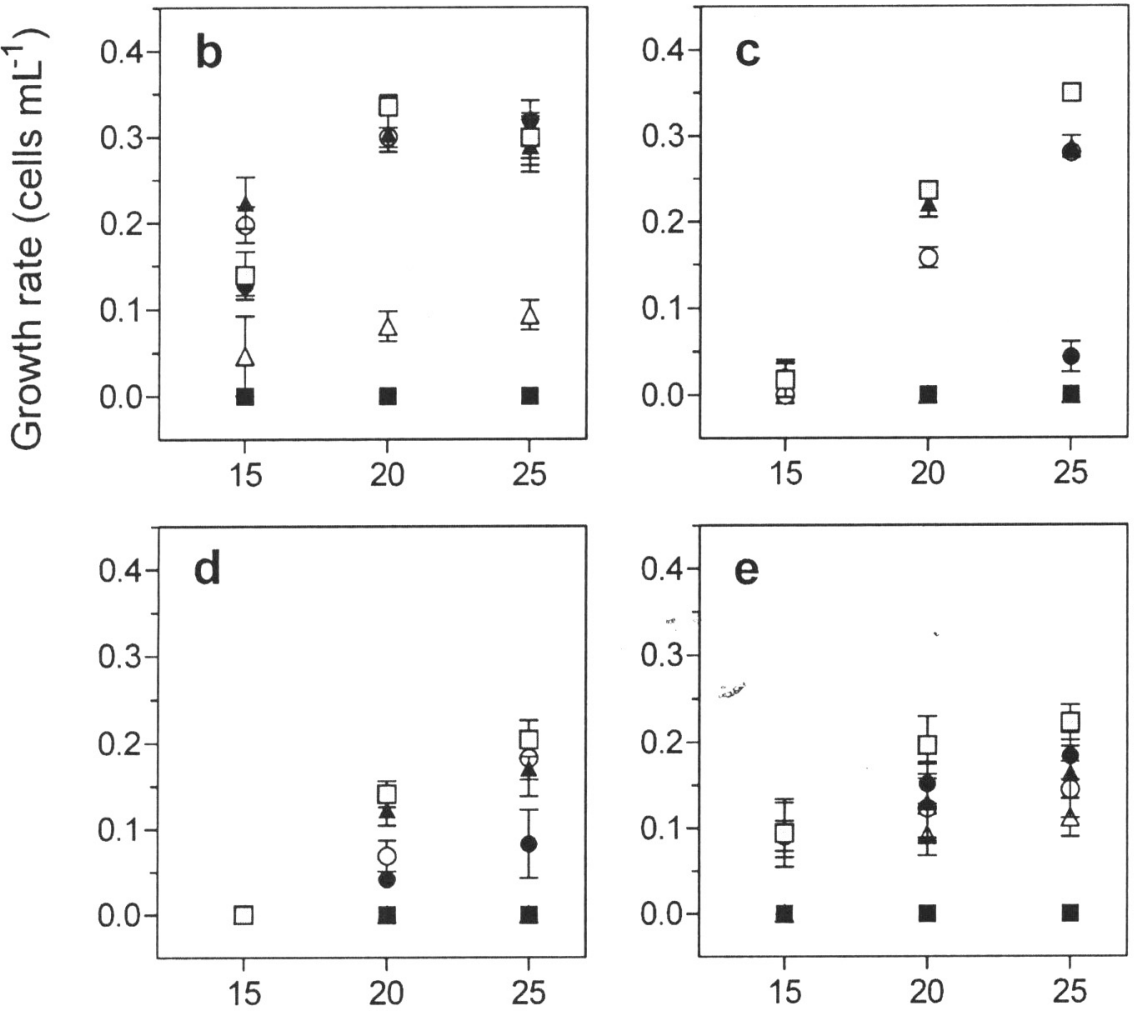

Temperature ${ }^{\rho} \mathrm{C}$ )

Figure 3. Specific growth rates of Alexandrium species under variable salinity and temperature conditions, (a) $A$. affine, (b) A. insuetum, (c) A. fraterculus, (d) A. leei, (e) A. pseudogoniaulax.

vary significantly in the optimum temperature regime $\left(20-25^{\circ} \mathrm{C}\right)$. However, the growth rates decrease significantly at suboptimum temperature $(\mathrm{P}<0.01)$. The species grew suboptimally at a salinity of $10 \mathrm{psu}$ in the temperature range examined $\left(0.05-0.10\right.$ day $\left.^{-1}\right)$ but did not survive at 5 psu.

The salinity range for optimum growth of $A$. fraterculus was $20-30$ psu $\left(0.16-0.35\right.$ day $\left.^{-1}\right)$. The growth rates decreased significantly at lower temperature $(\mathrm{P}<0.01)$. No growth was observed below 10 psu. In contrast, $A$. leei and $A$. pseudogoniaulax showed lower growth rates compared to the other three species. At optimum temperatures range, A. pseudogoniaulax could tolerate a wide salinity range of $10-30$ psu with growth rates of $0.10-0.22$ day $^{-1}$. At suboptimum temperature, the cells could not survive at salinity below 15 psu but grew at salinities between 20 to $30 \mathrm{psu}\left(0.10\right.$ day $\left.^{-1}\right)$. The tropical $A$. leei possessed almost similar optimum growth pattern as the tropical A. affine although with lower growth rates. The cells grew optimally at salinities between 20 to $30 \mathrm{psu}$ and cells died off at salinities below 10 psu. 


\section{DISCUSSION}

Temperature is one of the pivotal environmental factors to understand the ecological and physiological conditions of microlagae and their surrounding habitats, as temperature regulates the key biological processes in organisms, including photosynthesis, cellular enzymatic activities and respiration.

Effect of temperature on these key biological processes would result in changes of growth rates (Raven and Geider, 1988). Temperature effects on survival and growth also useful in explaining the biogeographical distribution of a particular macro and microalgae species (Pakker and Breeman, 1996). In the present study, growths of Alexandrium species varied significantly with temperature. The highest growth rate for all the species examined was obtained at the upper temperature range between 20 to $25^{\circ} \mathrm{C}$. This temperature range was coincided with the temperature range of subtropical to tropical waters that are consistently more than $20^{\circ} \mathrm{C}$, and the water temperature during summer in the temperate waters. However, the temperate species showed an optimum temperature range which was higher than expected from their natural habitats and exhibited a broader tolerance to temperature compared to the tropical strains. At suboptimum temperature $\left(15^{\circ} \mathrm{C}\right)$, the temperate species grew suboptimally while both tropical strains of $A$. affine and $A$. leei showed no positive growth. The results obtained in this study supported the hypothesis that the temperate strains can adapt wider temperature ranges. In Sanriku coast of Northeastern Japan, where the temperate strains originated from, the temperature at $5-10 \mathrm{~m}$ depth varied significantly with the lowest temperature observed in winter $\left(6^{\circ} \mathrm{C}\right)$ and the highest at late summer $\left(20^{\circ} \mathrm{C}\right)$. However, warm water condition only stay on for a short period of time (less than 3 weeks). Occurrence of these species was reported from warmer month from September to November (Kaga et al., in press). No blooms of these species have been observed thus far over the four-year period (2000-2003) (Kaga et al., in press).

Growth response to temperature observed in the tropical $A$. affine was similar to that with tropical A. tamiyavanichii (previously as $P$. cohorticula, Ogata et al., 1989). Both tropical and temperate $A$. tamiyavanichii showed an optimum growth at $25^{\circ} \mathrm{C}$ but the temperate strains showed better tolerance to lower temperature limit (Ogata et al., 1989). Our results also consistently agreed with the previous findings and supported the hypothesis that temperate strains could tolerate broader temperature ranges.

Interestingly, our result on the effect of temperature was also in agreement with the proposed life form types of Smayda and Reynold (2001). The five species fell within the life form type of IV, V and VI that consisted of raphidophytes and almost all toxic dinoflagellates (Smayda, 2006). The PST-producing $A$. tamiyavanichii and $A$. minutum also fell in this group (Lim et al., 2006). However, the Alexandrium species examined in the present study belong to non PST-producing strains. This indicated that the life form type IV, V and VI not only consisted of toxic species but might also include some other non toxic dinoflagellates.

Salinity is important in determining the horizontal distribution of a species in estuaries. Numerous bloom events of toxic Alexandrium have been associated with the estuarine waters (Cembella and Therriault, 1989; Lim and Ogata, 2005) Giacobbe et al. (1996) had shown that the spring blooms of $A$. minutum in Mediterranean Sea were coincided with the increase in rainfall and freshwater run off. Low salinity coastal current in the Gulf of Maine has also shown to promote cell proliferation of $A$. tamarense in Casco Bay regions (Anderson, 1998).

Salinity tolerance of the five species in decreasing order was $A$. pseudogoniaulax $>A$. leei $>A$. insuetum $>A$. affine $>A$. fraterculus. It is interesting to note that there were vast variations in salinity tolerance observed among the Alexandrium. The hypothesis that tropical species showed stronger salinity tolerance is rejected based on the result obtained in present study. Both the tropical $A$. affine and $A$. leei strains showed a high salinity optimum between 20 to 30 psu and could not tolerate salinity below 10 psu.

Difference degree of salinity tolerance was also exhibited in the tropical PST-producing Alexandrium species (Lim and Ogata, 2005). Among the Alexandrium species found in Malaysia waters, $A$. minutum has been shown to be strong euryhaline with optimum salinity range between 5 to $30 \mathrm{psu}$, while $A$. tamiyavanichii showed no positive growth at salinity below 20 psu. This was consistent with the habitats of the species where $A$. tamiyavanichii, $A$. affine and 
A. leei were isolated from waters with salinity of $28 \mathrm{psu}$, and with less influence of freshwater plumes (Usup et al., 2002; Lim et al., 2006).

Presence of selective pressure in the environments was probably the reason for ecotypic variation. For example, among the $A$. minutum species, higher salinity optimum strains and wide salinity optimum strains have been observed from different localities. Most of the A. minutum strains showed optimum salinity that is higher than $15 \mathrm{psu}$ (Chang and McClean, 1997; Grzebyk et al., 2003). The Malaysian and Taiwanese strains showed wide salinity tolerance from 3 to more than $30 \mathrm{psu}$ (Hwang and Lu, 2000; Lim and Ogata, 2005). Adaptation of Alexandrium species in the estuarine waters will depend on the capability to tolerate salinity fluctuation. The allochthonous species might be transported into the estuary by tidal currents from outside the estuary. Ability of the species to tolerate salinity fluctuation will give an advantage in the availability of terrestrial derived nutrients. In estuaries water with long residence time, populations of autochthonous plankton species may grow and develop. Result of the present study showed that at least four species, i.e. A. affine, $A$. insuetum, $A$. leei and $A$. pseudogoniaulax were able to maintain growth in brackish water environment. This ability gives an edge over other species that showed narrow salinity tolerance, such as $A$. fraterculus (present study) and A. tamiyavanichii (Lim and Ogata, 2005).

In conclusion, the temperate Alexandrium examined in this study exhibited a high tolerance to temperature while the tropical species had a weak tolerance to lower temperature. This implied that the chances of the tropical species to proliferate in temperate environments remain insignificant. However, adaptation of the temperate species at warm tropical temperatures indicated that these species might dominate in warmer water if the species was transported by means of natural or human activities.

Acknowledgements. A research fellowship was given to P.-T. Lim by the University of Malaysia Sarawak and the Malaysian Government. This study was financially supported by a Grant in Aid for Scientific Research from the Ministry of Education, Science and Culture, Japan to T. Ogata and the Universiti Malaysia Sarawak Short term research grant to P.-T. Lim.

\section{REFERENCES}

Anderson, D. M. 1998. Physiology and bloom dynamics of toxic Alexandrium species, with emphasis on life cycle transitions. In: Anderson, D. M., Cembella, A. D. \& Hallegraeff, G. M. [Eds.] Physiological Ecology of Harmful Algal Blooms. Springer-Verlag, Berlin-Heidelberg, pp. 29-48.

Anderson, D. M., Kulis, D. M., Sullivan, J. J. \& Hall, S. 1990. Toxin composition variation in one isolate of the dinoflagellate Alexandrium fundyense. Toxicon 28: 885-93.

Cembella, A. D. and Therriault, J. C. 1989. Population dynamics and toxin composition of Protogonyaulax tamarensis from the St. Lawrence estuary. In: Okaichi, T., Anderson, D. M. \& Nemoto, T. [Eds.] Red Tides-Biology, environmental Science and Toxicology. Elsevier, New York, pp. 81-85.

Chang, F. H. and McClean, M. 1997. Growth responses of Alexandrium minutum (Dinophyceae) as a function of three different nitrogen sources and irradiance. New Zealand J. Mar. Freshwater Res. 31: 1-7.

Delgado, M., Garces, E., Vila, M. and Camp, J. 1997. Morphological variability in three populations of the dinoflagellate Alexandrium taylori. J. Plankton Res. 19: 749-57.

Flynn, K., Franco, J. M., Fernandez, P., Reguera, B., Zapata, M., Wood, G. \& Flynn, K. J. 1994. Change in toxin content, biomass and pigments of the dinoflagellate Alexandrium minutum during nitrogen refeeding and growth into nitrogen or phosphorus stress. Mar. Ecol. Prog. Ser. 111: 99109.

Giacobbe, M. G., Oliva, F. D. and Maimone, G. 1996. Environmental factors and seasonal occurrence of the dinoflagellate Alexandrium minutum, a PSP potential producer, a Mediterranean lagoon. Est. Coast. Shelf Sci. 42: 539-49.

Grzebyk, D., Bechemin, C., Ward, C. J., Verite, C., Codd, G. A. and Maestrini, S. Y. 2003. Effects of salinity and two coastal waters on the growth and toxin content of the dinoflagellate Alexandrium minutum. J. Plankton Res. 25: 1185-99.

Hwang, D. F. and Lu, Y. H. 2000. Influence of environmental and nutritional factors on growth, toxicity, and toxin profile of dinoflagellate Alexandrium minutum. Toxicon 38: 1491-503.

Kaga, S., Sekiguchi, K., Yoshida, M. and Ogata, T. in press. Occurrence and toxin production of Alexandrium spp. (Dinophyceae) in coastal water of Iwate Prefecture, Japan. Nippon Suisan Gakkaishi. 
Kokinos, J. P. and Anderson, D. M. 1995. Morphological development of resting cysts in cultures of the marine dinoflagellate Lingulodinium polyedrum (= L. machaerophorum). Palynology 19: 143-66.

Lim, P.-T., Leaw, C.-P., Usup, G., Kobiyama, A., Koike, K. and Ogata, T. 2006. Effects of light and temperature on growth, nitrate uptake, and toxin production of two tropical dinoflagellates: Alexandrium tamiyavanichii and Alexandrium minutum (Dinophyceae). J. Phycol. 42: 786-99.

Lim, P.-T. and Ogata, T. 2005. Salinity effect on growth and toxin production of four tropical Alexandrium species (Dinophyceae). Toxicon 45: 699-710.

Ogata, T., Kodama, M. and Ishimaru, T. 1987. Toxin production in the dinoflagellate Protogonyaulax tamarensis. Toxicon 25: 923-28.

Ogata, T., Kodama, M. and Ishimaru, T. 1989. Effect of water temperature and light intensity on growth rate and toxin production of toxic dinoflagellates. In: Okaichi, T., Anderson, D. M. \& Nemoto, T. [Eds.]
Red Tides: Biology, Environmental Science, and Toxicology. Elsevier, New York, pp. 423-26.

Pakker, H. and Breeman, A. M. 1996. Temperature responses of tropical to warm- temperate Atlantic seaweeds. II. Evidence for ecotypic differentation in amphi-Atlantic tropical-Mediterranean species. Eur. J. Phycol. 31: 133-42.

Raven, J. A. and Geider, R. J. 1988. Temperature and algal growth. New Phytologist 110: 441-61.

Smayda, T. J. 2006. DInoflagellate and raphidophyte blooms and the $15^{\circ} \mathrm{C}$ barrier. 12th International Conference on Harmful Algae. Abstract. Copenhagen, Denmark., pp. 31

Smayda, T. J. and Reynolds, C. S. 2001. Community assembly in marine phytoplankton: application of recent models to harmful dinoflagellate blooms. $J$. Plankton Res. 23: 447-61.

Usup, G., Leaw, C. P., Ahmad, A. and Lim, P. T. 2002. Alexandrium (Dinophyceae) species in Malaysian waters. Harmful Algae 1:265-75. 